
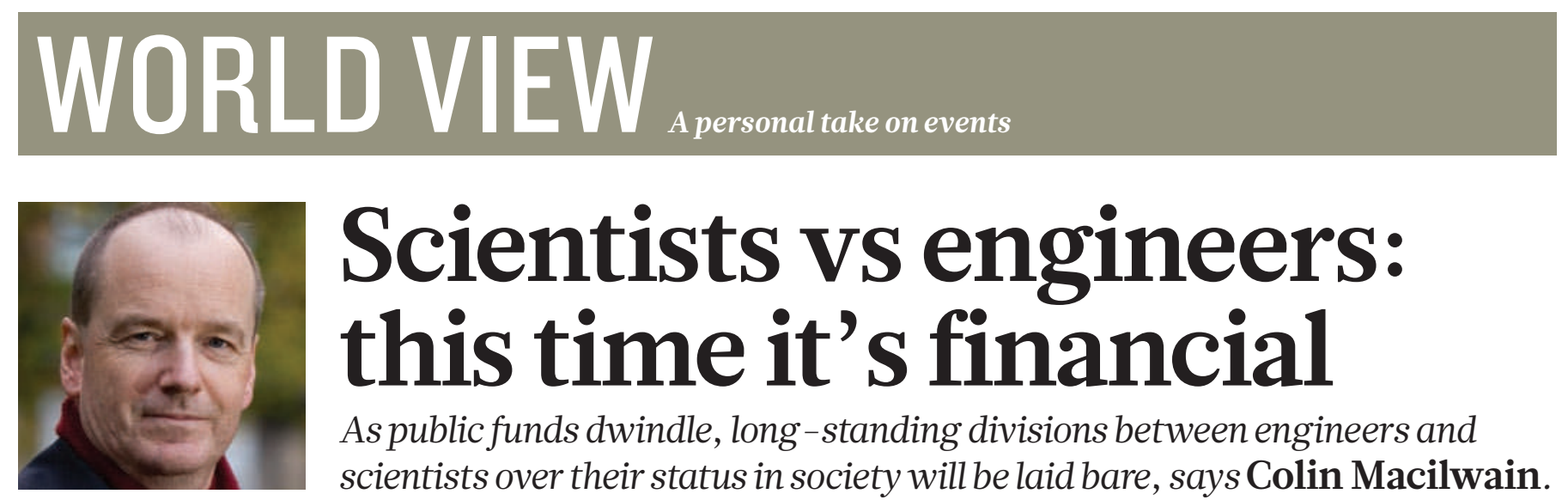

\title{
Scientists vs engineers: this time it's financial
}

\author{
Aspublic funds dwindle, long-standing divisions between engineers and \\ scientists over their status in society will be laid bare, says Colin Macilwain.
}

$\mathrm{M}$ y name is Colin, and some time ago, I trained as an engineer. I live in the United Kingdom, where engineering has a longstanding status problem, best summed up by the greeting: "If you're an engineer, I've got a lawnmower that needs fixing." I used to live in America, whose engineers also often feel that they don't get the respect they deserve from scientists, policy-makers or the public at large.

Engineers seem to enjoy higher status outside the English-speaking world - in France, Germany, Japan or China, for example. Perhaps that's for deep-seated cultural reasons, or maybe it's just because the English word 'engineer' is associated so directly with old engines. In fact, the term derives from the Latin ingenium, or talent.

Science is mainly concerned with unearthing knowledge. Engineering seeks to deliver working solutions to practical problems in the form of technology. Yet the terms 'engineering' and 'technology' have been increasingly subsumed into 'science' - in the names of institutions, in discussion of 'science policy', in media coverage and in popular parlance. The situation upsets engineers and their leaders, but they tend to keep quiet for fear of being accused of having chips on their shoulders.

Now that public money is scarce for both the science and engineering communities, the fault line between them has started to creak. In the run-up to this week's UK Comprehensive Spending Review, Martin Earwicker, a vice-president at the Royal Academy of Engineering (RAEng), wrote to The Times to point out that engineers are needed to turn a scientific discovery into hard cash. It was a "logical leap that is not in general supported by experience", he wrote, "that a scientific discovery, however important, will automatically turn into economic success."

This was not the first dig at science from Britain's top engineering body. In its June submission to the spending review, it said: "Although particle physics research is important, it makes only a modest contribution to the most important challenges facing society today, as compared with engineering and technology where almost all the research is directly or indirectly relevant to wealth creation." This frankness angered scientific groups, including the Institute of Physics and the Royal Society. The engineers' crime was to say what a number of others, not just in Britain, think in private. William Wulf, a computer scientist at the University of Virginia in Charlottesville, was president of the US National Academy of Engineering from 1996 to 2007, where he repaired relations with its elder sibling, the National Academy of Sciences. Despite that success, he maintains that "there is a general attitude among the scientific community that science is superior to engineering".

Wulf attributes this partly to the 'linear' model of innovation, which holds that scientific Discuss this article online at:

go.nature.com/ze5c4g

\section{$\rightarrow$ NATURE.COM}

discovery leads to technology, which in turn leads to human betterment. This model is as firmly entrenched in policy-makers' minds as it is intellectually discredited. As any engineer will tell you, innovations, such as aviation and the steam engine, commonly precede scientific understanding of how things work. Engineers also grumble about how the media report on science, but give almost no coverage to engineering or technology development.

These slights are probably felt most keenly by engineers in academia: their colleagues in industry have other things to think about, such as their superior pay, company cars and career opportunities.

During the long economic boom that ended in 2008, divisions between engineers and scientists over how government should spend money lay largely dormant. They've been stirred back to life because of threatened spending cuts, and by the realization that strong university science isn't enough to secure industrial competitiveness.

The RAEng said in its submission that each active research academic in physics and maths gets 'several times more expenditure' than those in engineering and technology. But industry spends twice as much - about $£ 15$ billion (US $\$ 23.8$ billion) - as the UK government on research and development each year, and most of that industrial money supports engineering, not science. In addition, state programmes that concentrate on applied work - such as the European Commission's Framework Programme - tend to be more politicized, less meritocratic and less efficient than science programmes such as those of the US National Science Foundation.

So there is a strong case that the UK government should focus its attention on science. Even so, some of the questions from engineers deserve answers. The United States and Britain have dominated science for decades, but the productive sectors of their economies remain weak. Until 2008, there was remarkable complacency in both countries about their wholesale retreat from high-value-added manufacturing. Germany, with weak research universities but strong engineering labs in both the public and private sectors, exported a larger value of goods last year than either of them.

With money so tight, research priorities in Britain and the United States face re-examination. It is axiomatic that scientists won't do this: their central operating principle is not to upset the next person's rice bowl. If politicians try to set priorities, they'll be assailed for interfering and 'picking winners. That leaves yesterday's habits as the main way to allocate tomorrow's resources. By casting a stone at their rivals, UK engineers have, at least, demanded better. They've also started a scrap between disciplines that will grow uglier as the spending cuts begin.

Colin Macilwain is a contributing correspondent with Nature. e-mail:cfmworldview@gmail.com 